\title{
The potential of tropical grass as a feed in ruminant by using an in vitro gas production
}

\author{
Nevyani Asikin ${ }^{1, *}$, Anuraga Jayanegara ${ }^{2}$, Muhamad Ridla ${ }^{2}$, and Anjas Asmara Samsudin ${ }^{3}$ \\ ${ }^{1}$ Graduate School of Nutrition and Feed Science, Faculty of Animal Science, Bogor Agricultural University, Jl. Agatis Kampus IPB \\ Darmaga Bogor 16680, Indonesia \\ ${ }^{2}$ Department of Nutrition and Feed Technology, Faculty of Animal Science, Bogor Agricultural University, Jl. Agatis Kampus IPB \\ Darmaga Bogor 16680, Indonesia \\ ${ }^{3}$ Department of Animal Science,Faculty of Agriculture, Universiti Putra Malaysia, Serdang Selangor Darul Ehsan 43400, Malaysia
}

\begin{abstract}
Pennisetum purpoides is one of the most widely cultivated tropical forages and it is often used as animal feed in Indonesia. However, grass feeding could not fulfill the need of nutrients if served as single feed because it contained of high crude fiber and low protein. In terms of nutritional adequacy, animal feed should contain complete nutritional value in order to achieve an optimum productivity. This experiment aimed to elucidate the potential of tropical grass as a feed in ruminant by using an in vitro gas production technicque. The grasses were determined for proximate analysis, Van Soest fiber fractions (neutral detergent fiber, acid detergent fiber and acid detergent lignin), and in vitro rumen fermentation parameters. This study was conducted from January until April 2018 at Nutrition Laboratory, Department of Animal Science, Faculty of Agriculture, University Putra Malaysia, Serdang Selangor Darul Ehsan, Malaysia. This study used a randomized block design with 3 replications. There were three treatments tested in this study, i.e. (1) Pennisetum purpoides (T1), (2) Setaria splendida (T2), (3) Setaria anceps (T3). Parameters measured in the in vitro study is total gas production. Data were tested using analysis of variance (ANOVA) and continued with Duncan test if there was a significant difference among treatments. The data showed that gas production is not significantly different $(\mathrm{P}>0,05)$.
\end{abstract}

\section{Introduction}

The grass is one of the foremost sources of energy for ruminant livestock, which acts as a triggering factor in order for the rumen to function normally so that it affects health and productivity [1]. Pennisetum purpoides is one of the most widely cultivated tropical forages and it is often used as animal feed in Indonesia. However, grass feeding could not fulfill the need of nutrients if served as single feed because it contained of high crude fiber and low protein. In terms of nutritional adequacy, animal feed should contain complete nutritional value in order to achieve an optimum productivity such as for meat and milk producers. Therefore, the fulfillment and optimization of decent nutritional value of grasses are needed.

Setaria splendida and setaria anceps are palatable tropical forages that can be used as cut grass and pasture grass. Setaria splendida contained high protein value, easily to grow and produce well even in dry season while setaria anceps have been frequently used as animal feed and to enhance digestibility [2]. However, these grasses are still seldomly used by stock farmers.

The use of feed alternatives has often been recommended in order to supply the nutritional deficiencies of the herds. Tropical forages generally have low $\mathrm{N}$ content. Thus, the use of forage species with higher levels of $\mathrm{N}$ could improve the ruminal environment. However, in order to rationally use an ingredient in animal feed it is necessary to characterize it, which involves knowledge not only of its chemical composition, but its eff ects on ruminal fermentation.

Nutritional evaluations of a region's available feed is clearly important, so these evaluations can make decisions regarding the selection of forage species, and adapt the databases of feed formulation systems to meet the nutritional requirements of the animals. Concomitantly, adjusted diets make it possible to achieve higher production performance, decrease excessive costs from providing excess nutrients and reduce environmental waste products [3]. The purpose of this study is to elucidate the potential of tropical grass as a feed in ruminant by using an in vitro gas production technicque.

\section{Material and method}

\subsection{Experimental plants}

The feed plants used in this study consisted of Pennisetum purpureum, Setaria splendida and Setaria anceps which collected from the Agrostology field laboratory in

\footnotetext{
* Corresponding author: nevyaniasikin $@$ gmail.com
} 
Department of Nutrition Science and Feed Technology, Faculty of Animal Science, Bogor Agricultural University. The part of the feed plant taken is the edible part (plant parts that can be consumed by livestock except roots). A total of $1 \mathrm{~kg}$ wet crops harvested are chopped into smaller parts. The feed plants were placed into the oven at $60^{\circ} \mathrm{C}$ for 48 hours before milled into 1 millimeter mesh size by grinder (miller machine). There were three treatments tested in this study, for instances, (1) Pennisetum purpoides (T1), (2) Setaria splendida (T2), (3) Setaria anceps (T3). This study was conducted from January to April 2018 at Nutrition Laboratory, Department of Animal Science, Faculty of Agriculture, Universiti Putra Malaysia, Serdang Selangor Darul Ehsan, Malaysia.

\subsection{Chemical Content Analysis}

The content of dry matter (DM), organic matter (OM), crude protein $(\mathrm{CP})$, crude fat $(\mathrm{CF})$ and crude fiber $(\mathrm{CFb})$ of grass samples were determined according to the AOAC method [4], while neutral detergent fiber (NDF), acid detergent fiber (ADF), and acid detergent lignin (ADL) are estimated according to the method of Van Soest [5].

\subsection{Total gas measurement}

In vitro gas production is determined by methods proposed by Menke \& Steingass [6]. A total of $200 \mathrm{mg}$ of substrate was weighed and inserted into $100 \mathrm{ml}$ syringe (Model Fortuna, Häberle Labortechnik, Germany). The buffer solution is made just before the experiment and it is placed into water bath at $39^{\circ} \mathrm{C}$ at the same time flowing with $\mathrm{CO}_{2}$ gas. Thirty milliliters of buffer solution mixture and rumen fluids $(2: 1)$ were added into the tube at the same time flowing with $\mathrm{CO}_{2}$ gas to maintain anaerobic condition. The syringe was incubated into water bath at $39^{\circ} \mathrm{C}$ for 72 hours. Gas production was measured at 3, 6 , $9,12,24,48$ and 72 hours of incubation.

\subsection{Statistical analysis}

The obtained data were statistically analyzed by using ANOVA (Analysis of Variance) with SPSS 16.0. The significant vary data were tested further by Duncan's test [7]. Outlier data are being taken out ased on statistical justification so that distribution of data is normal. The experiment was designed using Group Random Design with 3 groups as replicates. Group is the difference between incubation (rumen fluid).

\section{Result and discussion}

This study has used a tropical forage which contained a variety of nutrition. The chemical composition analysis of feed results used as substrate on in vitro fermentation were stated in Table 1. Sample of PP grass contained the highest fiber among other grasses. In terms of SS grass sample protein, it has the highest protein content compare to PP and SA samples. The protein content results are not correlated with the total gas produced as illustrated as in
Figure 1. Whereas the highest gas production is SA grass sample.

The NDF content is considered high enough to affect the digestibility value which directly affect gas production. These three grasses contained high percentage of NDF content which ranging from $88-90 \%$. Majority of the NDF are cellulose and lignin fractions that usually form lignocellulosic bonds which is difficult to digest by rumen microorganisms. Other than affecting digestibility, NDF content also affects methane gas emission. Methane content increases along with the increasing of NDF content [8].

Table 1. Chemical composition of forage species expressed in $(\mathrm{g} / \mathrm{kg} \mathrm{DM})$ used in the study.

\begin{tabular}{|c|c|c|c|}
\hline $\begin{array}{c}\text { Chemical } \\
\text { composition (\%) }\end{array}$ & PP & SS & SA \\
\hline DM & $93.67^{\mathrm{a}}$ & $93.24^{\mathrm{b}}$ & $93.85^{\mathrm{a}}$ \\
\hline OM & $86.31^{\mathrm{c}}$ & $90.74^{\mathrm{b}}$ & $91.29^{\mathrm{a}}$ \\
\hline $\mathrm{CP}$ & $23.57^{\mathrm{b}}$ & $31.9^{\mathrm{a}}$ & $23.15^{\mathrm{b}}$ \\
\hline $\mathrm{CF}$ & 0.8 & 2.01 & 3.15 \\
\hline $\mathrm{CFb}$ & 33.13 & 27.29 & 31.18 \\
\hline $\mathrm{NDF}$ & 88.66 & 90.1 & 88.04 \\
\hline $\mathrm{ADF}$ & 40.7 & 39.92 & 40.56 \\
\hline $\mathrm{ADL}$ & 18.45 & 20.76 & 20.05 \\
\hline
\end{tabular}

Note : PP, Pennisetum purpupoides; SA, Setaria splendida; and SA, Setaria ancep; DM, dry matter; OM, Organic matter; CP, crude protein; $\mathrm{CF}$, crude fat; $\mathrm{CFb}$, crude fiber; $\mathrm{NDF}$, neutral detergent fiber;ADF, acid detergent fiber; ADL, acid detergent lignin

$a b c$ Values on the same row with different superscript differ.

Table 2 numerically showed that the total gas production experienced increases along with the length of incubation time. It can be seen SA grass yields the highest total gas, followed by PP and SS grasses. However, statistical results showed three types of grass have no significant effect $(\mathrm{P}>0.05)$ towards total gas.

Table 2. Total gas production throughout incubation.

\begin{tabular}{|c|c|c|c|}
\hline \multirow{2}{*}{ Treatment } & \multicolumn{3}{|c|}{ Time Incubation (Hour) } \\
\cline { 2 - 4 } & 24 & 48 & 72 \\
\hline PP & 19.58 & 32.67 & 37.25 \\
\hline SS & 18.75 & 28.67 & 29.00 \\
\hline SA & 22.58 & 34.67 & 39.08 \\
\hline SEM & 0.98 & 1.59 & 2.78 \\
\hline P Value & 0.297 & 0.398 & 0.468 \\
\hline
\end{tabular}

The gas production showed the fermentation process of feed take place by microbes. The total gas production rate of the three types of grass in rumen fermentation system in vitro for 72 hours is presented in Figure 1. The study results showed that the grass type does not have significant effect $(\mathrm{P}>0.05)$ towards gas production. Total gas production for all method increases along with the length of incubation time. 


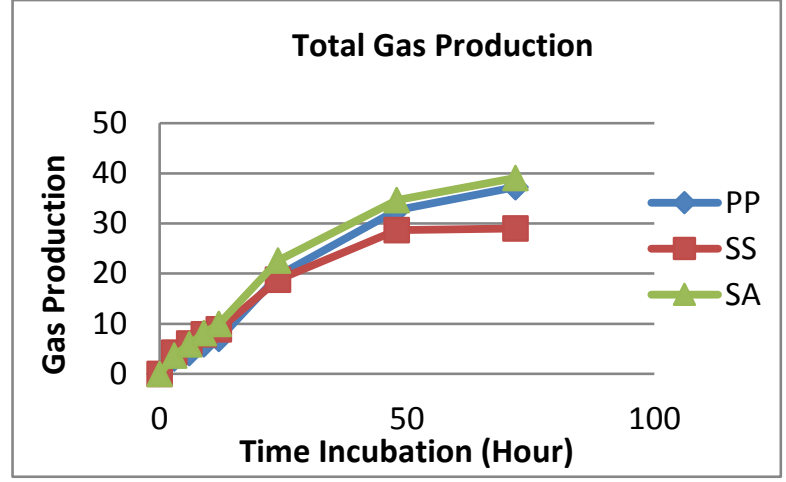

Fig. 1. Kinetic production of total gas.

The gas produced by rumen microbes during incubation is largely a product resulted from microbial metabolism in digesting and fermenting feed or substrate, while other parts are the result from buffering process of artificial saliva solutions (Buffer solution) towards the production of Volatile Fatty Acids [9]. Figure 1 explains that the rate or rate of gas production is becoming slower with increasing length of incubation time. The condition of fewer digestible substrate with increasing length of incubation lead to slower rate of gas production [10]. [11] Stated that, the gas production shows the fermentation and degradation processes take place in rumen and it shows the amount of organic material digestible in rumen. The formation of gas from fermentation process consisted of $56 \% \mathrm{CO}_{2}, 32 \%$ methane gas $\left(\mathrm{CH}_{4}\right), 8.2 \% \mathrm{~N}_{2}$ and $3.5 \% \mathrm{O}_{2}$ [12]. It was concluded three kind of grasses has potential as ruminant feeds which proved by gas production profile with in-vitro technique.

This research is a part of the collaboration between Universiti Putra Malaysia and Bogor Agricultural University. I wish to thank Lembaga Pengelola Dana Pendidikan (LPDP) Indonesia for funding this research and laboratory team of Animal Nutrition, Department of Animal Science, Faculty of Agriculture, Universiti Putra Malaysia for involved in most of the work it's related.

\section{References}

1. L. Abdullah. Bulletin Faculty of Agricultural University 58, 125-128 (2006)

2. D.T. Sabrina, M. M. Hanafi, A.W. Gandahi, M. T. M. Mohamed, \& N. A. A. Aziz. Aust. J. Crop Sci. 7, 75-83 (2013)

3. P. A. T. Velásquez, T.T. Berchielli, R. A. Reis, A.R. Rivera, P.H.M. Dian, I.A.M.A. Teixeira, R. Bras. Zootec. 39, 1206-1213 (2010)

4. [AOAC] Association of Analytical Communities, Official Methods of Analysis of AOAC International (18th Ed) (Association of Official Analytical Chemical, Arlington US, (2005)

5. P.J. Van Soest. Anim Feed Sci Technol 130, 137171 (2006)

6. K.H. Menke. Anim Res Develop 28, 7-55 (1998)
7. R.G.D. Steel, J.H. Torrie. Prinsip \& Prosedur Statistika. Suatu Pendekatan Biometrik. (Gramedia Pustaka Utama, Jakarta, 1993), pp.

8. A. Jayanegara, H.P.S. Makkar, K. Becker. Proc Soc Nutr Physiol 18, 98 (2009)

9. G. Getachew, M. Blummel, H.P.S. Makkar, K. Becker. Anim Feed Sci Technol 72, 261-281, (1998)

10. A. Jayanegara, T. Sabhan, A.K. Takyi, A.O. Salih, E.M. Hoffmann. J Develop Trop Anim. 35, 165-171 (2010)

11. Fisrori. "Manfaat Tepung Daun Kelor (Moringa Oleifera, Lam) Dan Gliciridia (Gliciridia Sepium,Jacq) Sebagai Sumber Protein Dalam Urea Molases Blok (Umb) Terhadap Metabolisme Pakan Secara In Vitro Dan Produksi Susu Sapi Perah" thesis, Brawijaya University (2005)

12. Arora Sp. Pencernaan Mikroba pada Ruminansia. (Gadjah Mada University Pres, Yogyakarta, 1989), pp. 